\title{
Comparability of Accounting Choices in Future Valuation of Investment Properties: An Analysis of Brazilian and Portuguese Listed Companies*
}

Flaida Êmine Alves de Souza

Universidade Federal de Uberlândia, Faculdade de Ciências Contábeis, Uberlândia, MG, Brazil

Reiner Alves Botinha

Universidade Federal de Uberlândia, Programa de Pós-Graduação em Ciências Contábeis, Uberlândia, MG, Brazil

Pablo Rogers Silva

Universidade Federal de Uberlândia, Faculdade de Gestão e Negócios, Uberlândia, MG, Brazil

Sirlei Lemes

Universidade Federal de Uberlândia, Faculdade de Ciências Contábeis, Uberlândia, MG, Brazil

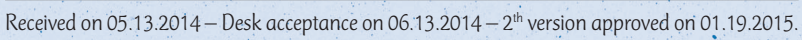

\begin{abstract}
One of the main purposes for adopting the International Financial Reporting Standards (IFRS) is the quest for comparability between financial statements within the same country, over time, and between different countries. IFRS have the feature of allowing accounting choices in most of their standards. However, the existence of such flexibility in the process for recognizing, measuring, and disclosing assets and liabilities may impact on comparability. IFRS have been criticized both due to their accounting choices and the adoption of the fair value paradigm. This article examines these two issues, investigating the choice of the cost model versus the choice of the fair value model for investment properties (IPs), an option guaranteed under the terms of the International Accounting Standard (IAS) 40. This research aimed to identify the comparability degree and the factors that determine the accounting choices made by managers of IPs, in Brazilian and Portuguese listed companies, within the periods from 2010 to 2012. Comparability, within and between countries, was identified by the T-index and the search for the determining factors of accounting choices made by managers was performed by means of a logistic regression analysis. As a result, it was found that, despite the accounting choices allowed by IAS 40, there was a mean comparability between the accounting practices of firms in these countries, but showing a decrease in the index over the years. The explanatory factors identified were auditing by one of the big four (PricewaterhouseCoopers, Deloitte Touche Tohmatsu, KPMG, or Ernst \& Young), companies' indebtedness, relative importance of IPs' balance, net profit, and less experience of Brazil in using the fair value method to appraise IPs.
\end{abstract}

Keywords: comparability, accounting choices, IAS 40, investment properties. T-index. 


\section{INTRODUCTION}

The International Financial Reporting Standards (IFRS), issued by the International Accounting Standards Board (IASB), emerged to solve the need for reliable, good-quality, transparent information (Oliveira \& Lemes, 2011), as well as "information divergence problems generated by accounting reports" (Lemes \& Carvalho, 2009, p. 26).

The accounting convergence process has, as one of its main features, the quest for comparability between financial reports within a country, over time, and between different countries (Cairns, Massoudi, Taplin, \& Tarca, 2011). In order to enable such comparability, i.e. so that the same events look alike and different events look like different (International Accounting Standards Board, 2013, item QC 23), IFRS have some choices about the several stages of accounting for an equity element, named herein as accounting choices.

One of the possible accounting choices, when applying IFRS, is measuring after initial recognition (subsequent valuation) of investment properties (IPs), which can be appraised according to the fair value or the acquisition cost, as provided for by the International Accounting Standard (IAS) 40. Through this choice, a question arises concerning the existence (or not) of comparability between the financial reports of firms that recognize the IPs, since they can be appraised in two different ways.

IFRS have been criticized both due to the flexibility (accounting choices) they provide and to the adoption of the fair value paradigm (Muller, Riedl, \& Sellhorn, 2008). Thus, this article examines these two issues, investigating the choice of the cost model versus the choice of the fair value model for IPs, an option guaranteed under the terms of IAS 40. As a result, the purpose is answering to this question: "What is the comparability degree and which are the factors that determine the accounting choices made by managers of IPs, in Brazilian and Portuguese listed companies, regarding measurement after initial recognition?"

To meet the purpose of this research, we analyzed the financial statements of 50 Brazilian firms listed on the Stocks, Commodities, and Futures Exchange of São Paulo (BM\&FBOVESPA) and 23 Portuguese firms listed on the Lisbon Stock Exchange (NYSE Euronext Lisbon), within the periods from 2010 to 2012 .

These periods were selected because, to examine the comparability of accounting choices between the two countries, it was regarded as needed to consider the last corporate fiscal years, since the year in which the use of IFRS became mandatory in both. In Portugal, the compulsory adoption of the International Accounting Standards took place for the fiscal years ended since 2005 (Regulation 1,606/2002, from the European Parliament), and in Brazil, from the fiscal years ended since 2010 (Instruction CVM 457/2007).

The selection of listed companies belonging to Brazil and Portugal was due to the fact that Macedo, Machado, and Machado (2013) emphasized that the attempt to bring Brazilian accounting closer to the accounting of
Anglo-Saxon countries, by adopting IFRS, did not succeeded, and in most companies accounting remained based on practices influenced by Roman Law - the Code Law regime. In countries ruled by this legal system, like Portugal and countries that were colonies in South America, such as in the case of Brazil, laws tend to be the normative basis for the accounting practice.

Thus, the Brazilian legal model brings along with it a legacy of the Portuguese colonization process, especially during the validity of the local generally accepted accounting principles (GAAP), marked by a Roman system that appreciates that the law should be applied in compliance with regulatory instruments, with a reduced (or minimum) amount of subjectivism in accounting practices. After IFRS adoption, accounting based on principles and marked by subjectivism has gained a space of its own. These International Standards, due to their Anglo-Saxon origin, are regarded as legitimate representatives of the accounting model based on the Common Law system (Nobes, 1998; Carmo, Ribeiro, \& Carvalho, 2011), different, therefore, from the system of the countries studied in this research.

Considering the similarities between Brazil and Portugal, the impact of these factors on IFRS adoption, as well as the recent adoption, by both countries, of a concept inherent to a Common Law system - fair value -, the following hypothesis has provided the study with a basis:

$\mathrm{H}_{\mathrm{o}}$ : The accounting choices made by managers of IPs, in Brazilian and Portuguese listed companies, regarding valuation after recognition, are highly comparable, according to the environmental similarities of the two countries.

This study contributes to the literature by identifying possible differences in financial statements, within and between countries, over time, in relation to the accounting choices contained in IAS 40. Variation between the valuation of IPs through the cost method or the fair value method can affect the comparability of reports and it suggests implications that flexibility, in decisions about financial statements, can lead to highly divergent choices by the firms (Muller et al., 2008).

In addition to the contributions introduced, the study bridges a current gap of investigations on accounting choices, pointed out by Fields, Lys and Vincent (2001), as it is focused on a relatively new theme - fair value - in the Brazilian accounting scenario, it shows the distinction of analyzing the choices made by two countries historically linked, over three years, and it also seeks possible explanations for the choices made by companies regarding the valuation after recognition of IPs.

This research is structured into four parts, besides this introduction. In section two the theoretical framework is introduced; in section three, the methodological procedures adopted in the research; in section four, the results are described and analyzed; finally, we draw the final remarks on the results obtained. 


\section{THEORETICAL FRAMEWORK}

\subsection{Comparability}

According to Van der Tas (1988, p. 158), "two reports are comparable in relation to a specific case, if in the same circumstances of this event, both reports or multiple reports, are accounted for in the same way." According to the author, an effective way to enable comparability might be by establishing standards, which would set limits to the differences between them.

From a normative viewpoint, IFRS stress the need for comparability between reports, periods, and countries, to make accounting information more useful to users' decision-making. In fact, IFRS have brought, among the qualitative improvement features listed for the preparation of financial statements, comparability, which, added with other features (verifiability, timeliness, and understandability), provides a good-quality accounting information (International Accounting Standards Board, 2013).

Thus, one of the primary purposes of IFRS adoption consists in improving comparability of financial statements (Cairns et al., 2011), which is nothing more than making the same economic phenomena look like the same and different economic phenomena look like different, rather than making different phenomena look like the same, and vice versa (International Accounting Standards Board, 2013). Thus, there lies the justification for the existence and persistence of accounting choices in IFRS: offer alternatives so that managers register accounting facts in order to issue comparable financial reports.

Comparability may be approached from different perspectives. One of them is the distinction between de jure (or formal) and de facto (or informal) comparability. Another distinction has been made between comparability over time and between different companies within the same country or from more than one country. A third perspective addresses the comparability between accounting numbers, voluntary disclosure, press releases, and so on (Cole, Branson, \& Breesch, 2009).

This research was focused on measuring the comparability of accounting numbers by analyzing financial statements. To do this, the so-called comparability indices were used, which are mathematical mechanisms created in order to measure the comparability degree between accounting reports of firms over time and between countries. Van der Tas (1988), the forerunner to the creation of these indices, proposed the indices $\mathrm{H}, \mathrm{C}$, and I, all of them with the purpose of measuring the comparability degree between accounting reports, however, each with specific peculiarities. Taplin (2004), in his turn, developed the T-index, which covers, in a single index, all specificities of the previous ones, in addition to correcting their limitations.

The H-index is used when one intends to investigate the comparability of financial statements of companies belonging to a single country, when firms have the possibility to use only one accounting method. The C-index shows up as an evolution of the H-index, because, besides enabling the calculation of national comparability, it considers multiple accounting choices. The I-index was created with the purpose of measuring international comparability (more than one country), but it does not take into account the number of companies or the size of the countries under investigation.

The T-index, the most complete of them all, has the following properties: (i) comparison between countries with a different number of companies; (ii) analysis within the country, between countries, and general (international focus); (iii) analysis of multiple accounting policies; and (iv) specific treatment when there is no disclosure of the accounting choice made by the entity (Taplin, 2004). Therefore, this indicator is the most appropriate for this research.

\subsection{Accounting Choices}

On the way towards IFRS adoption, accounting starts a transition process, from an accounting based on rules to an accounting based on principles and rules, in order to better represent the economic and financial situation of companies, something which has led accounting subjectivism coming from professional judgment to be emphasized (Bennett, Bradbury, \& Prangnell, 2006; Barth, 2008; Gabriel \& Corrar, 2010).

This accounting subjectivism observed in IFRS is provided by the discretion allowed in their scope, by means of accounting choices. Watts (1992) defines accounting choices as a manager's choice of a method over another. Fields et al. (2001, p. 256), in their turn, define accounting choices as:

[...] any decision, whose main purpose is influencing (either in form or substance) the output of the accounting system in a particular way, including not only the financial statements issued in accordance with GAAP, but also tax returns and regulatory filings.

It is worth stressing, however, that such professional subjectivism provided by accounting choices did not emerge to the detriment of enhancing flexibility in the accounting practices under financial statements, but according to Fields et al. (2001), with a view to meet the needs of an incomplete and imperfect market, which requires a system of accounting standards that protect the many users of accounting information, faced with the agents' interests.

Nevertheless, accounting theory does not have a rule that guides managers to choose this or that accounting method. It only provides explanations on the reasons leading certain companies to use a method, rather than another, as well as the implications of specific choices, something which becomes significant for accounting professionals, as it provides tools for better decision-making in face of the various situations caused by a scenario of continued change (Watts \& Zimmerman, 1986).

Due to sharp criticism, in the past, to its process of issuing documents with two approaches allowed for several of its standards (a benchmark and an alternative treatment), the IASB has undertaken efforts with the firm intent to redu- 
ce them. It was, in a way, successful. Nevertheless, choices at different levels still remain. Could complete elimination of such choices generate more comparable accounting reports? The answer is yes. Would this generate accounting reports that do not adequately represent the economic events they are intended to represent? Probably not.

Thus, the existence of accounting choices in IFRS is an implicit and needed feature for the generation of accounting reports useful for decision making. Weighting and equalizing their use, without compromising the comparability intended for these reports, still remains a controversial subject in need of further discussion.

\subsection{Investment Properties}

Investment property, regulated by IAS 40 (item 5), issued by the IASB, is defined as "property (land or a building or part of a building or both) held (by the owner or by the lessee under a finance lease) to earn rentals or for capital appreciation or both [...]"

IAS 40 provided significant changes in international accounting, such as listed by Muller et al. (2008). First, the revaluation model was deleted, an option allowed to account for IPs, in which, according to the author, it was considerably supported as appropriate accounting approach to measure IPs. Second, it was the first time that the IASB applied the fair value model to non-financial long-term assets. Finally, the standard provided the firms with the option to choose between cost and fair value, as accounting policy for valuation after recognition of IPs.

The IPs, however, should be measured, initially, by their cost, including the transaction costs (IAS 40, item 20). After recognition, in the subsequent assessment, IAS 40 (item 30) provides that an entity should choose, as its accounting policy, between the cost method or the fair value method, and this policy should be applied to all of its recognized IPs.

Prior to IFRS adoption, "investment property assets were accounted for under the domestic accounting standards applied within the firm's country of domicile" (Muller et al., 2008, p. 7). As for Brazil and Portugal, the main differences between the International Standard and the local accounting regulations regarding IPs, prior to the adoption of IAS 40, are displayed in Table 1.

Differences between the Brazilian and Portuguese legislations previous to IAS 40

\begin{tabular}{|c|c|c|c|}
\hline Subject & Brazil & Portugal & International \\
\hline Applicable standard & Law 6,404/76. & Accounting Guideline 16 (DC 16). & IAS 40. \\
\hline $\begin{array}{l}\text { Measurement after } \\
\text { initial recognition }\end{array}$ & $\begin{array}{l}\text { Uses for all recognized IPs, in } \\
\text { accordance with art. } 183 \text {, IV, of Law } \\
6,404 / 76 \text { : the acquisition cost model, } \\
\text { by deducting: } \\
\text { (i) provisions for probable losses at } \\
\text { the realization of their value; or } \\
\text { (ii) provisions for cost deduction from } \\
\text { market value, if it has a lower value. }\end{array}$ & $\begin{array}{l}\text { Uses for all recognized IPs, in accordance with DC } \\
\text { 16: } \\
\text { (i) the cost model; } \\
\text { (ii) the model of variation in the currency's } \\
\text { purchasing power; or } \\
\text { (iii) the fair value model. }\end{array}$ & $\begin{array}{l}\text { Use for all recognized IPs: } \\
\text { (i) the cost model; or } \\
\text { (ii) the fair value model. }\end{array}$ \\
\hline $\begin{array}{l}\text { Characterization of } \\
\text { the fair value }\end{array}$ & Not applicable to the IPs. & $\begin{array}{l}\text { IPs' accounting value: fair value at the date of } \\
\text { valuation, by deducting from amortization and } \\
\text { accumulated impairment losses. } \\
\text { - Recognizes gains derived from revaluation } \\
\text { directly on the entity's equity, in the } \\
\text { revaluation reserve account. } \\
\text { Recognizes losses derived from revaluation } \\
\text { as a decrease in the revaluation reserve } \\
\text { established in the company's equity, up to the } \\
\text { limit of its balance. After the limit, losses are } \\
\text { recognized directly in the revenue within the } \\
\text { period. }\end{array}$ & $\begin{array}{l}\text { - IPs' accounting value: fair } \\
\text { value at the date of valuation. } \\
\text { - Recognizes gains from change } \\
\text { in fair value directly in profit } \\
\text { for the the period. } \\
\text { - Recognizes losses arising from } \\
\text { a valuation directly in the loss } \\
\text { for the period. }\end{array}$ \\
\hline
\end{tabular}

Source: Prepared by the authors.

It is worth emphasizing that the fair value model established by IAS 40 for IPs' revaluation was not allowed by local standards before IFRS, in most European countries (Muller et al., 2008) or in other countries, such as Brazil. According to the fair value model, IPs are booked in the balance sheet at their fair value and any changes in their value are recognized directly in income statement (Muller et al., 2008). According to the authors, this recognition directly in revenue has, perhaps, brought substantial volatility to the reported net profit, that is the reason why it was not allowed in many countries.

\subsection{Method Fair Value versus Cost Method}

Fair value is defined as "the price that would be received to sell an asset or paid to transfer a liability in an orderly transaction between market participants at the measurement date" (IFRS 13, item 9). The choice between the fair value and the historical cost models is one of 
the most widely debated issues in the accounting literature (Christensen \& Nikolaev, 2013).

The application of IFRS in Europe, for instance, has brought many changes in the traditional continental accounting practices (Demaria \& Dufour, 2007). European countries have a conservative accounting and IFRS adoption, especially in the recognition at fair value of certain assets and liabilities, represents a radical perspective change for preparers and users (Bertoni \& Derosa, 2005; Demaria \& Dufour, 2007).

As for the benefits of using a method rather than another, according to Christensen and Nikolaev (2013), valuation at fair value seems to be better than historical cost in most qualitative features described in the Conceptual Framework for Financial Reporting (International Accounting Standards Board, 2013). "The only exception is, arguably, the reliability criterion on which historical cost is likely to score higher" (Christensen \& Nikolaev, 2013, p. 736). Although estimates at fair value tend to be more relevant, it is less likely they are reliable (Dietrich, Harris, \& Muller, 2001).

Comparability, for instance, provides better quality in accounting information, in order to allow users to identify similarities and differences between two sets of economic phenomena (Herrmann, Saudagaran, \& Thomas, 2006). According to Herrmann et al. (2006), the fair value method, when reliably measured, improves comparability of financial reports, while the cost method may hamper comparability, both by failing to identify similarities between similar items and by not distinguishing differences between different items.

According to Shaffer (2010), those advocating for the use of fair value, also the members of the Financial Accounting Standards Board (FASB), the IASB, and the Securities and Exchange Commission (SEC), argue that this method provides stakeholders with more transparent, timely, and accurate information. They claim that the fair value model improves market discipline, enabling more effective markets, and that "the alternative measurement models (lower of cost or market and historical cost) hide or delay the disclosure of important information and produce inefficient market decisions" (Shaffer, 2010, p. 4).

Despite the benefits assigned to fair value, its use is relatively limited, since it is used only when reliable estimates are available at a reduced cost and when they convey information on the entity's operating performance (Christensen \& Nikolaev, 2013). Critics of the fair value claim that its use "can increase income volatility, undermine public confidence and adversely affect economic stability" (Shaffer, 2010, p. 4). According to Shaffer (2010), critics state, too, that fair values cannot have any relation to expected cash flows or the economy; they may contain determinants arising from the market's feeling and not from economic fundamentals or conditions.

Furthermore, usually, the IPs are appraised annually by external assessors and these values are reflected in the firms' accounting reports (Nellessen \& Zuelch, 2011).
According to Nellessen and Zuelch (2011), this process of IP valuation at fair value gives rise, in the professional and academic community, to a considerable skepticism about the reliability of the valuation of these properties. According to these authors, the literature points out that valuations are prone to uncertainties and insecurities due to a number of assessor's features.

According to Freri and Salotti (2013), factors such as market fluctuation, especially at times of crisis, the need for specific expertise (such as that in civil engineering) and the subjectivism in assessor's judgment are some of the factors that can lead to inadequate measurement of IPs' fair value. The very human nature of external assessors, the way how the valuation process is conducted, and the essence and operation of the real estate market corroborate to increase the probability of obtaining biased fair values (Nellessen \& Zuelch, 2011).

\subsection{Previous Studies}

Dietrich et al. (2001) investigated 76 firms in the UK, within the periods from 1988 to 1996 , aiming to identify the reliability of annual estimates of fair value in IPs. They found out that fair value estimates have values, on average, $6 \%$ lower than the actual selling prices of real estate, indicating a conservative trend in assessors' judgments. Notwithstanding, the authors claim that fair value estimates are selling price measures considerably less biased and more accurate than their respective historical costs. By investigating the managerial criteria, they observed that the existence of accounting choices enables managers to choose methods that provide, for instance, higher profits, something which entails opportunities for earning management. They also found that the reliability of fair value estimate of increases when monitored by external auditing, particularly if auditing is performed by companies known at the time as the "big six": Arthur Andersen, Coopers \& Lybrand, Deloitte \& Touche, Ernst \& Young, KPMG Peat Marwick, and Price Waterhouse.

Also focusing on measurement reliability, Muller III and Riedl (2002) sought evidence that the reliability differences in estimates of professional assessors, due to using external monitors, affected informational asymmetry of investors and, therefore, the cost of capital. By using a sample with 64 companies in the UK, from 1990 to 1999 , the authors point out that market agents realize lower information asymmetry in investors for companies that use external assessors when compared to those using internal assessors for valuation after recognition of IPs.

Demaria and Dufour (2007) studied IFRS adoption for the first time in 107 French firms in 2005, from the perspective of accounting choices on the valuation at fair value. As for IPs (IAS 40), out of the 33 firms that recognized them, 9 chose the fair value method and 24 the cost method, noticing a strong conservative trend in the accounting reports of the French firms. Through a logistic regression analysis, the authors found that, for the 
companies under study, the adoption of fair value is not related to any of the features analyzed, namely: entity's size, financial leverage, managers pay, and structure of common shares held by banks, insurance companies, or investment funds.

Muller et al. (2008) examined the causes and consequences of managers' choice between IPs' fair value and cost methods, in 133 firms from 15 European countries in 2005. Out of the firms analyzed, 27 chose the cost method and 106 the fair value method. The authors found evidence that the firms that choose the fair value are those whose: (i) local standards (before IFRS) allowed or required this valuation method in the balance sheet; (ii) properties were more dispersed; and/or (iii) firms were seeking greater transparency in accounting statements. They also noticed evidence of opportunism by the firms that appraised their IPs at fair value, as they had higher profits, lower information asymmetry, and higher liquidity, when compared to firms that appraised these assets by the cost method.

Focusing on information power and using a sample with 446 real estate companies and 915 investment funds within the periods from 1993 to 2002, Danbolt and Rees found that profit at fair value is considerably more relevant than profit at historical cost, although this relevance can be transmitted through assets' value and it does not require fair value to be incorporated into the measurement of profit. In the same line of research on the relevance of information in fair value vis-à-vis historical cost, Lourenço (2009) pointed out that the accounting numbers were more relevant for European companies in the real estate sector included in the sample that measured investments in properties at fair value than those using the cost model.

Nellessen and Zuelch (2011) analyzed the reliability of fair value estimates in IPs' valuation in 76 European companies within the periods from 2005 to 2007. To do this, they examined the association between equity and market value of these firms. The results showed that there is a difference between these values and that these deviations may derive from: (i) the lack of confidence in the estimation of IPs' fair value due to limitations in the valuation; (ii) the diversity of approaches applied to the valuation of IPs; and (iii) the reliability problem in the approaches by models usually applied in determining the IPs' fair value.

Cairns et al. (2011) investigated the use of measurement at fair value in 228 listed companies in the UK and in Australia, at the time of initial IFRS adoption, in 2005.
As for the IPs (IAS 40), out of the 23 firms that recognized them, 17 chose the fair value method and 6 the cost method. The authors found that, in relation to IAS 40 , comparability within and between countries have significantly decreased because some UK companies used the option available in this standard.

Christensen and Nikolaev (2013) studied the accounting choice fair value versus historical cost in non-financial assets (intangible, fixed assets, and IP) of firms, in accordance with IFRS, in 2005 or in 2006, with 703 listed companies in the UK and 605 in Germany. Overall, they found a very limited use of valuation by the fair value method, indicating that "despite its conceptual merits, fair value is unlikely to become the primary valuation method for illiquid non-financial assets on a voluntary basis" (Christensen \& Nikolaev, 2013, p. 734).

Freri and Salotti (2013) analyzed the comparability of six Brazilian companies, shopping center management companies, which held IPs' balance, in 2010 and 2011. They sought to verify which firms appraised these assets by using the cost method and which resorted to the fair value method, besides checking whether these companies complied with the mandatory disclosures contained in IAS 40. The authors found that only 2 firms appraised their IPs by using the fair value method in the 2 years analyzed and that no company fully complied with the mandatory disclosure requirements contained in the standard.

Finally, Andrade, Silva and Malaquias (2013) investigated the accounting choices in IPs of 39 Brazilian companies listed on the BM\&FBOVESPA, in 2009 and 2010. They identified that, out of the firms making up the sample, $44 \%$ adopted the fair value method and 56\% resorted to the cost method. It also became clear that none of the variables selected for the study - assets size, indebtedness, corporate governance level, and return on equity (ROE) - showed a statistically significant relation to the valuation method chosen by the firms.

In general, studies on fair value point out better information capacity when compared to historical cost. Despite these benefits, the researchers identify limited use of fair value and a certain distrust level regarding the measurement method, probably due to the fact that the studies focus on the first year of IFRS adoption. Explanatory factors for choosing the fair value also indicate revenue management through the greater discretionary power of managers in their choice. However, the studies are not conclusive and further research is needed, especially considering time periods longer and more distant of the first IFRS adoption.

\section{METHODOLOGICAL ASPECTS}

\subsection{Sample Definition and Data Collection}

The research sample consisted of 73 listed companies, 50 Brazilian and 23 Portuguese, for the fiscal years 2010 to 2012. The identification of Brazilian firms and their respec- tive IPs balances was performed through the software Economatica and the search for notes was conducted on the website of BM\&FBOVESPA. On the other hand, the identification of Portuguese firms was conducted through the 
website of NYSE Euronext Lisbon, and the search for IPs accounts' balances and notes took place on the website of the Securities Market Commission (CMVM) of Portugal.

In 2013, 378 listed Brazilian companies were identified, out of which 328 did not have IPs' balances in 2010, 2011, and/or 2012. Thus, 50 firms in Brazil made up the study sample. Regarding Portugal, in 2013, 54 firms listed on the stock exchange were identified. Out of these, 31 did not have IPs' balance in 2010, 2011, and/or 2012, something which led the sample of Portuguese companies to be made up of 23 listed companies.

\subsection{Calculation of the Comparability Index}

To measure the comparability degree of accounting choices between firms and countries, the calculation of T-index (T-index) was used, whose Equation 1 is reported by Taplin (2004, p. 61):

$$
\mathrm{T}_{\text {lndex }}=\sum_{i=1}^{N} \sum_{j=1}^{N} \sum_{k=1}^{M} \sum_{l=1}^{M} \alpha_{k l} \beta_{i j} P_{k i} P_{l j}
$$

where $\mathrm{T}$ index represents the comparability degree; $\alpha_{k l}$ is the comparability coefficient between the accounting methods $\mathrm{k}$ and $1 ; \beta_{i j}$ is the weight for comparing companies from countries $\mathrm{i}$ and $\mathrm{j} ; \rho_{k i}$ is the proportion of companies from country $\mathrm{i}$ using the accounting method $\mathrm{k} ; \rho_{l j}$ is the proportion of companies from country $\mathrm{j}$ using the accounting method $\mathrm{l} ; \mathrm{N}$ is the amount of countries analyzed; and $\mathrm{M}$ is the amount of accounting methods analyzed (Taplin, 2004).

The index ranges between 0 and 1 , where 0 represents a complete disharmony between the financial statements of firms and 1 represents a complete harmony (Taplin, 2004). T-index may be interpreted as the probability that two companies, randomly selected (with replacement), show the same accounting practices (Taplin, 2004).

In order to interpret the national (of each country separately) and international comparability degrees (the two countries together) of accounting choices in IPs, the scale proposed by Souza, Silva and Costa (2013) was used, it is illustrated in Table 2 .

\begin{tabular}{cc}
\hline T-index & Comparability \\
\hline Between 0.700 and 1.000 & High \\
Between 0.500 and 0.699 & Mean \\
Between 0.000 and 0.499 & Low \\
\hline
\end{tabular}

Source: Adapted from Souza et al. (2013).

The calculation of national and international T-indices were carried out by using the software T-Index Calculator $^{1}$. We used the modality 1(a)2(a)3(a)4(a), that is: (i) weighting company/country: countries were weighted, in order to have equal weights, considering that the country receives a weight proportional to the number of companies in the sample of each country; (ii) international focus: comparisons are made between all firms, regardless of the country to which they belong (general focus); (iii) several accounting policies: multiple accounting policies are not allowed; and (iv) non-disclosure: firms that did not disclose the accounting method adopted were excluded from the sample and from the index calculation (Taplin, 2010).

\subsection{Logit Model}

In order to examine empirically whether specific features of the firms affect their accounting choices, some explanatory variables were surveyed, which have been partly analyzed in the studies by Demaria and Dufour (2007), Jaafar and Mcleay (2007), Muller et al. (2008), Lourenço (2009), Lorencini and Costa (2012), and Andrade et al. (2013). Firms that did not disclose their IPs' valuation policy were excluded from the sample, but only in the year for which there was no disclosure. Thus, the variables that made up the model are displayed in Table 3 . 
Table 3

Model variables

\begin{tabular}{|c|c|c|c|}
\hline Variable & Denomination & Specification & Proxy \\
\hline AC & Accounting choice & Companies that recognized IPs at cost or fair value. & Dummy variable: $0=$ cost; 1 = fair value. \\
\hline SECT & Operating sector & $\begin{array}{l}\text { Companies classified according to the operating } \\
\text { sector on BM\&FBOVESPA. }\end{array}$ & $\begin{array}{l}\text { A dummy variable for each sector: } 1=\text { industrial } \\
\text { goods; } 2=\text { construction and transport; } 3=\text { cyclic } \\
\text { consumption; } 4=\text { non-cyclic consumption; } 5=\text { finan- } \\
\text { cial and others; } 6=\text { primary materials; } 7=\text { telecom- } \\
\text { munications; } 8=\text { public utility; } 9=\text { real estate. }\end{array}$ \\
\hline LIST & Listing status & $\begin{array}{l}\text { Companies exposed or not to the international } \\
\text { market (issuers or not ADRs or GDRs). }\end{array}$ & Dummy variable: $0=$ domestic; $1=$ international. \\
\hline BF & Big four & $\begin{array}{l}\text { Companies audited by one of the firms regarded as } \\
\text { belonging to the big four. }\end{array}$ & $\begin{array}{l}\text { Dummy variable: } 0=\text { not audited by a big four; } 1= \\
\text { audited by a big four. }\end{array}$ \\
\hline COUNT & Country & This variable represents the countries analyzed. & Dummy variable: 0 = Portugal; 1 = Brazil. \\
\hline SIZE & Company's size & $\begin{array}{l}\text { Company's size measured by total assets in } 2010 \text {, } \\
\text { 2011, and } 2012 \text {. }\end{array}$ & Natural logarithm of total assets ${ }^{\mathrm{a}}$. \\
\hline ROE & Return on equity & $\begin{array}{l}\text { Return on equity measured by dividing net profit by } \\
\text { net equity in 2010, 2011, and } 2012 \text {. }\end{array}$ & $\begin{array}{l}\text { Result of the relation between net profit and net } \\
\text { equity }{ }^{a} \text {. }\end{array}$ \\
\hline RELEV & $\begin{array}{l}\text { Relevance of IPs' balance } \\
\text { in relation to total assets }\end{array}$ & $\begin{array}{l}\text { Relative relevance of IPs measured by dividing IPs' } \\
\text { balance by total assets in 2010, 2011, and } 2012 \text {. }\end{array}$ & Result of the relation between IP and total assets ${ }^{\mathrm{a}}$. \\
\hline NP & Net profit & $\begin{array}{l}\text { Companies that made profit or loss in 2010, 2011, } \\
\text { and/or } 2012 .\end{array}$ & $\begin{array}{l}\text { Dummy variable: } 0=\text { showed positive revenues } \\
\text { (profit); } 1 \text { = showed negative revenues (loss) }{ }^{\text {a }} \text {. }\end{array}$ \\
\hline $\mathbf{T}$ & Time & Period analyzed in years. & Dummy variable: $1=2010 ; 2=2011 ; 3=2012$. \\
\hline
\end{tabular}

The base date for such values is related to 31/12 each year. All values were converted into reais.

Source: Prepared by the authors.

It is noticed that the dependent variable (AC) takes only two values, something which makes it necessary to use binary qualitative choice models, such as linear probability models (LPMs), Probit and Logit. We chose the logit model because, as claimed by Johnston and DiNardo (2001): (i) seemingly in practice, there is little difference between these three models, thus the choice might be indifferent; (ii) LPM has as a deficiency the fact that predicted values are not restricted to the interval $(0,1)$, and its use should be avoided in some situations; and (iii) specification tests in the Logit models are more user-friendly and easy to apply. Furthermore, a simulation was performed by using the Probit method, and it was found that the statistical results were almost the same.

The general structure of the Logit models is based on probability analysis. Through a representation proposed by Johnston and DiNardo (2001), it is possible to illustrate the idea of the model adopted, according to Equation 2:

$$
\operatorname{Prob}\left(\mathrm{Y}_{\mathrm{i}}=1\right)=\mathrm{F}(\mathrm{X} \beta)
$$

where $\mathrm{Y}$ is the choice of Brazilian and Portuguese fir$\mathrm{ms}$ as for the method for valuation after recognition of IPs, which is equal to 1 if fair value is chosen and 0 if cost is chosen. $\mathrm{X}$ represents the matrix of explanatory variables listed in Table 3: SECT, LIST, BF, COUNT, SIZE, INDEBT, ROE, RELEV, NP, and T. $\beta$ is the set of parameters that reflect the impact of changes in X on the probability of a particular entity to choose the fair value method. $F$ is the logistic distribution function that turns an appropriate model $X \beta$ into an interval between 0 and 1 . In this case, it is possible to rewrite the model according to Equation 3:

$$
\operatorname{Prob}\left(\mathrm{Y}_{\mathrm{i}}=1\right)=\mathrm{P}_{\mathrm{i}}=\mathrm{F}\left(\mathrm{X}_{\mathrm{i}} \beta\right)=\frac{1}{1+\mathrm{e}^{-\mathrm{X}_{\mathrm{i}} \beta}}
$$

Considering an iid sample, the estimation of parameters $(\beta)$ of this model is obtained by maximizing the likelihood logarithm function (Equation 4):

$$
\ln L=\sum_{i=1}^{n} Y_{i} \ln \left[\frac{1}{1+\mathrm{e}^{-\mathrm{X}_{i} \beta}}\right]+\sum_{i=1}^{n}\left(1-Y_{i}\right) \ln \left[1-\frac{1}{1+\mathrm{e}^{-\mathrm{X}_{i} \beta}}\right]
$$

Model adjustments were checked by means of three tests: (i) to determine whether there are significant differences between observed and expected frequencies, we used the Hosmer-Lemeshow test; (ii) to verify the measures of sensitivity, specificity, and the model hit percentage, we used the classification table; and (iii) to measure the model's capacity to distinguish between categories of the dependent variable, we resorted to the Receiver Operating Characteristic (ROC) curve.

\section{DATA ANALYSIS}

\subsection{Results for the Calculation of Comparability}

To calculate the comparability degree between companies from Brazil, Portugal, and between the two countries, first, the notes of each company in each country were analyzed, by identifying the accounting choices as for the measurement after initial recognition of IPs, whose result is illustrated in Table 4. 


\begin{tabular}{|c|c|c|c|c|c|c|}
\hline & \multicolumn{3}{|c|}{ BRAZIL } & \multicolumn{3}{|c|}{ PORTUGAL } \\
\hline & 2010 & 2011 & 2012 & 2010 & 2011 & 2012 \\
\hline & $\mathbf{N}$ & $\mathbf{N}$ & $\mathbf{N}$ & $\mathbf{N}$ & $\mathbf{N}$ & $\mathbf{N}$ \\
\hline Measurement after initial recognition & 50 & 50 & 50 & 23 & 23 & 23 \\
\hline a) Cost method & 20 & 20 & 21 & 11 & 11 & 11 \\
\hline b) Fair value method & 13 & 15 & 17 & 11 & 11 & 12 \\
\hline c) Not disclosed & 17 & 15 & 12 & 1 & 1 & 0 \\
\hline
\end{tabular}

As for Brazil, it was noticed that the firms still have not shown the mandatory information on IPs in their notes, despite this non-disclosure has decreased over the corporate fiscal years checked. The results of this survey corroborate the findings of the study by Freri and Salotti (2013), who concluded that, among all Brazilian companies they analyzed in 2010 and 2011, none fully met the mandatory disclosure requirements contained in IAS 40. Regarding Portugal, only one entity did not disclose its policy of valuation after recognition of IPs, and only in 2010 and 2011. In 2012, all Portuguese firms provided evidence as to whether they have chosen the cost or fair value method to appraise their recognized IPs.

Concerning the disclosed accounting choices, although an increase in the number of firms that chose the fair value method has been noticed, over the periods under analysis, the Brazilian companies still maintain a preference for the cost method. This result confirms the evidence found in the studies by Freri and Salotti (2013) and Andrade et al. (2013), which, by examining Brazilian companies, identified, respectively, that $66.67 \%$ and $56 \%$ of the firms analyzed chose the cost method for valuation after recognition of IPs.

In the firms belonging to Portugal, a certain balance between the two possible methods for valuation after recognition of IPs was observed. The Portuguese firms have chosen both the fair value and the cost method, in an equivalent manner, and this choice has remained over time. These findings are contrary to the results of the research by Christensen and Nikolaev (2013), which, by observing the accounting choices in non-financial assets of European fir$\mathrm{ms}$ in 2005 and 2006, found that, on a voluntary basis, it is unlikely that the fair value becomes the primary valuation method for illiquid non-financial assets, such as the IPs.

Through the analysis of the comparability degree within and between countries, we calculated the national T-index for Brazil and Portugal, alone, and then we calculated the international T-score for the two countries, as shown in Table 5.

Table 5 Comparability degree (T-Index) in IPS

\begin{tabular}{lccc}
\hline T-INDEX & $\mathbf{2 0 1 0}$ & $\mathbf{2 0 1 1}$ & $\mathbf{2 0 1 2}$ \\
\hline Brazil's comparability & 0.5225 & 0.5102 & 0.5055 \\
Portugal's comparability & 0.5000 & 0.5000 & 0.5009 \\
International comparability & 0.5081 & 0.5038 & 0.5012 \\
\hline
\end{tabular}

For the Brazilian case, we notice a mean comparability (almost low) of accounting statements with decreasing values over the periods analyzed. This shows that, in relation to IPs, the comparability of accounting information from Brazilian firms has decreased every corporate fiscal year. For instance, for 2010, if two firms from Brazil are randomly selected, there is a $52.25 \%$ chance they have chosen for the same accounting method as for the valuation after recognition in IPs; in 2011, a 51.02\% chance; and in 2012, a 50.55\% chance.

Just as in Brazil, Portugal also had a mean comparability regarding the IPs, with values very close to a low comparability, but having values virtually unchanged over time. The mean comparability (almost low) of the financial statements was due to the fact that Portuguese firms choose both the cost and fair value methods in an equitable manner. For instance, in 2010 and/or 2011, if two firms from Portugal are randomly selected, there is a $50.00 \%$ chance they have chosen the same accounting method for valuation after recognition of IPs.
As for the comparability between the accounting statements of companies from Brazil and Portugal (international comparability), we found that it is mean, also showing values close to a low comparability. This was due to the fact that, internally, these two countries are divided between the two valid accounting policies, something which, as a consequence, leads this diversity to persist when the comparison is made between their firms, together.

\subsection{Results for the Logit Model Analysis}

Showing only the regression coefficients is not useful, unless we are interested only in their sign and significance (Hosmer \& Lemeshow, 2000). In this way, it is interesting, by means of the final model coefficients, to compute their marginal effects, which, in this case, allow assessing the impact on the probability that firms choose the fair value method ( $\mathrm{Y}=1)$, due to changes in the independent variables. Table 6 displays a summary of the results. 
Table 6

Summary of the Logit model with marginal effects

\begin{tabular}{|c|c|c|c|c|}
\hline $\mathrm{AC}$ & Marginal effects & Standard deviation & Z & $\mathbf{P}>|\mathbf{Z}|$ \\
\hline SECT2 & 0.0897 & 0.0996 & 0.9000 & 0.368 \\
\hline SECT3 & -0.3474 & 0.1100 & -3.1600 & $0.002^{* * *}$ \\
\hline SECT5 & 0.0028 & 0.1178 & 0.0200 & 0.981 \\
\hline SECT9 & -0.3528 & 0.1689 & -2.0900 & $0.037^{* *}$ \\
\hline LIST & -0.0112 & 0.1180 & -0.1000 & 0.924 \\
\hline BF & -0.1867 & 0.0932 & -2.0000 & $0.045^{* *}$ \\
\hline COUNT & -0.6090 & 0.3102 & -1.9600 & $0.050^{* *}$ \\
\hline SIZE & -0.0346 & 0.0361 & -0.9600 & 0.337 \\
\hline INDEBT & 0.2258 & 0.1070 & 2.1100 & $0.035^{* *}$ \\
\hline ROE & 0.0576 & 0.0798 & 0.7200 & 0.471 \\
\hline RELEV & 1.0141 & 0.2899 & 3.5000 & $0.000^{* * *}$ \\
\hline NP & -0.1971 & 0.0845 & -2.3300 & $0.020^{* *}$ \\
\hline T2 & 0.0452 & 0.0838 & 0.5400 & 0.590 \\
\hline T3 & 0.0432 & 0.0877 & 0.4900 & 0.622 \\
\hline Chi2(11) & & & & 39.93 \\
\hline Prob > chi2(11) & & & & 0.0003 \\
\hline Pseudo R2 & & & & 0.2768 \\
\hline Hosmer-Lemeshow (HL) & & & & 127.60 \\
\hline Prob > HL & & & & 0.5183 \\
\hline
\end{tabular}

SET is the dummy by sector, namely: SECT2 Construction and Transport, SECT3 Cyclic Consumption, SECT5 Financial and Others, and SECT9 Real Estate. The other sectors initially listed (SECT4 Non-Cyclic Consumption, SECT6 Primary Materials, SECT7 Telecommunications, and SECT8 Public Utility) showed no coefficients. LIST is the dummy for listing status, BF is the dummy for big four, COUNT is the dummy for country, SIZE represents the company's size, INDEBT represents the entity's indebtedness, ROE represents the return on equity, RELEV represents the IPs' balance relevance, NP is the dummy for net profit, and T is the dummy for time, where: T2 is 2011 and T3 is 2012. Statistical significance: * $p<0.1, * * p<0.05, * * * p<0.01$.

As for checking whether the entity's operating sector interferes with the choice of valuation after recognition method in IPs, it follows that the parameters for the sectors non-cyclic consumption, primary materials, telecommunications, and public utility were not estimated, due to the fact that the accounting choices for each sector were the same for both countries. That is, all firms in the sectors non-cyclic consumption and public utility chose the fair value method and all firms in the sectors primary materials and telecommunications chose the cost method.

Also in relation to the operating sectors of firms included in the sample, it was noticed that only two sectors influence on managers' decisions: cyclic consumption and real estate. By analyzing their marginal effect, the fact that the entity belongs to these sectors reduces by $34.74 \%$ (for the sector cyclic consumption) and $35.28 \%$ (for the sector real estate) the probability of choosing the fair value method.

By examining whether the variables listing status, big four, country, entity's size, indebtedness, ROE, relevance, net profit, and time interfere with managers' decisions, it was found that only the variables listing status, company's size, ROE, and time are not statistically significant. These findings confirm the conclusions by Demaria and Dufour (2007) and Andrade et al. (2013), i.e. the adoption of fair value is not related to the entity's size and ROE, and by Jaafar and McLeay
(2007), i.e. time does not interfere with using the fair value method. However, these findings do not corroborate the results found by Jaafar and McLeay (2007), who identified that the listing status is a determining factor for using fair value.

Regarding the variable $\mathrm{BF}$, it was found that the fact the entity is audited by a big four reduces by $18.67 \%$ the probability of choosing the fair value method. For the variable country, the fact the entity belongs to Brazil reduces by $60.9 \%$ the probability that the company chooses the fair value method. It is worth emphasizing that, in addition to the internal factors of each country, the fact that Brazil, before IFRS adoption, does not allow appraising IPs at fair value, may have been among the explanatory factors for such a result. This probable explanation is based on the study by Muller et al. (2008), who found evidence that the firms choosing to use the fair value tend to be those whose local standards allowed or required this valuation method.

As for the variable indebtedness, it was found that the fact that the company is in debt increases by $22.58 \%$ the probability to choose the fair value method for valuation after recognition of IPs. These results corroborate the findings of Christensen and Nikolaev (2013), who found that company's indebtedness is positively associated with choosing the fair value method.

Regarding the variable relevance, it was found that the greater the importance of IPs in relation to total assets, the 
greater the likelihood that the company choose the fair value method. There was also the fact that if the entity shows loss within the period, it reduces by $19.71 \%$ the probability to choose the fair value method to valuation after recognition of IPs. This result may indicate that, for the Brazilian and Portuguese companies, the choice of the fair value method may be justified for many reasons, but not to directly improve their results.
In order to detect whether there is an association between the observed and estimated values, we resorted to the Hosmer-Lemeshow test. At the nominal significance level of $5 \%$, it is found that there is an association between the observed and predicted values, i.e. the Logit model, proposed as shown in Table 6, may be regarded as having a good adjustment ( $p$ value $>0.05$ ). To analyze the hit percentage of the model applied, we prepared its classification table (Table 7).

Table 7

Model classification

\begin{tabular}{lcccc}
\hline \multirow{2}{*}{ OBSERVED $^{\mathbf{d}}$} & \multicolumn{3}{c}{ Valuation after recognition of IPs } & \% correct \\
\cline { 2 - 4 } & Fair value (+) & Cost (-) & Total & $70.00^{\mathrm{a}}$ \\
Fair value $=1$ & 49 & 16 & 65 & $78.38^{\mathrm{b}}$ \\
Cost $=0$ & 21 & 58 & 79 & $74.31^{\mathrm{c}}$ \\
Total & 70 & 74 & 144 & 74 \\
\hline
\end{tabular}

${ }^{\text {a }}$ sensitivity; ${ }^{\text {b }}$ specificity; ${ }^{\mathrm{c}}$ model's hit percentage. Cut-off point $=0.50$.

Concerning sensitivity, that is, the total amount of hits that the model shows as for the event of interest (manager's choice for appraising her/his IPs by using the fair value method), it is found out that the model correctly classifies $70 \%$ of the firms that chose the fair value. Nevertheless, regarding the specificity, that is, the total amount of hits that the model shows in relation to the non-event of interest (manager's choice for appraising her/his IPs by using the cost method), it follows that the model correctly classifies
$78.38 \%$ of the firms that chose the cost method. Therefore, it follows that, in general, the Logit model applied was able to correctly classify $74.31 \%$ of the observations analyzed.

Finally, to measure the logistic model's ability to discriminate categories of the dependent variable, we used the ROC curve, whose area was 0.8197 . Therefore, as the model's area has a value between 0.8 and 0.9 , it may be inferred that the model concerned has an outstanding discretionary power (Hosmer \& Lemeshow, 2000).

\section{FINAL REMARKS}

This study aimed to check the comparability degree of accounting choices made by managers in relation to the measurement after initial recognition of IPs provided for by IAS 40 , as well as identify which features of the companies might be regarded as explanatory factors for the comparability level found.

To achieve the proposed objective, we analyzed companies listed on BM\&FBOVESPA and NYSE Euronext Lisbon, in 2013, within the time frame from 2010 to 2012. In order to identify the comparability degree, we used Taplin's T-index and to identify the features of companies as explanatory factors a Logit model was estimated.

At the stage of identifying the comparability degree of accounting statements of Brazil and Portugal, there was a mean international comparability, with values close to a low comparability, motivated by the fact that both countries are divided between two valid accounting policies, something which impacts on the comparability of these countries. In addition, the comparability degree between the two countries has declined over the corporate fiscal years analyzed. Thus, $\mathrm{H}_{0}$ is not accepted, because the Brazilian and Portuguese listed companies, concerning the valuation after recognition of IPs, are not highly comparable, even considering the environmental similarities between the two countries.
As for the national comparability, it was found that Brazilian firms still do not show, on a full basis, the mandatory information about IPs, although this deficiency has slightly improved over the years observed. It was noticed, too, that there was a mean comparability (close to low) between their accounting statements, with decreasing values over the periods and a preference to choose the cost method, however, having a tendency to adopt the fair value method.

Regarding Portugal, unlike the Brazilian case, there was a higher disclosure level on the valuation after recognition of IPs, as well as a certain balance between the two valid methods for valuation after recognition. This last fact has led, similarly to the Brazilian case, Portugal to show a mean comparability, with values close to a low comparability.

Thus, the results obtained indicate that, despite the financial choices allowed by IAS 40 , there is a comparability between the accounting practices of Brazilian and Portuguese companies, in all periods observed in this survey. Another significant point to be reported is that, despite having more experience with IFRS, Portugal showed comparable rates lower than those exposed by Brazil. In this way, it is inferred that the experience with IFRS does not necessarily guarantee greater comparability of accounting practices. 
In reference to the features of companies realized as explanatory factors for managers' financial choices, it was found that big four, country, indebtedness, relevance of IPs' balance, and net profit were statistically significant rates, i.e. they influence on managers' choice in relation to the valuation after recognition of IPs. Thus, it was found out that the fact the entity is audited by a big four reduces the likelihood of choosing the fair value method by $18.67 \%$, something which denotes that auditors of the so-called big four can influence on a conservative way their customers when reporting IPs.

Regarding the variable country, it was found that the fact the entity belongs to Brazil reduces the likelihood that the company chooses the fair value method by $60.90 \%$. In addition to the intrinsic factors of each nation or each company, the fact that Brazil has not allowed using the fair value method before IFRS adoption (but Portugal has) may be one of the factors that justify this result.

As for the indebtedness, the fact that the company is in debt increases by $22.58 \%$ the probability that it chooses the fair value method. This result suggests that interest in paying off debts influences on the accounting choice of managers to use fair value as the method for appraising IPs. On the contrary, when there is net profit, the fact that the company has shown loss for the fiscal year does not influence on the accounting choice of managers for the fair value method. In this case, the probability that these firms choose this method is reduced by $19.71 \%$.

For the variable relevance, it was found that the higher the balance of IPs in relation to total assets, the greater the entity's likelihood to choose the fair value method in its subsequent valuation. Concerning the operating sectors, it was found that all firms belonging to the sectors non-cyclic consumption and public utility have chosen the fair value method and all firms belonging to the sectors of primary materials and telecommunications have chosen the cost method. As a result, these sectors did not have their parameters estimated by the model.
Besides, we found that the only sectors with significant influence on managers' decisions were cyclic consumption and real estate. The results denoted that the fact the entity belongs to the sector cyclic consumption reduces by $34.74 \%$ the chances of choosing the fair value method and that companies belonging to the sector real estate reduce by $35.28 \%$ the probability of choosing the fair value method.

The findings of this study contribute to the international literature, by supplementing previous studies (Muller et al., 2008; Cairns et al., 2011; Andrade et al., 2013; Christensen \& Nikolaev, 2013; Freri \& Salotti, 2013; Haller \& Wehrfritz, 2013; Souza et al., 2013), identifying that, even with the existence of accounting choices in IAS 40, there is comparability between the financial statements of firms from Brazil and Portugal.

The study also contributes to the literature by relying on the T-index, poorly explored in accounting research as well as by providing explanatory factors to the accounting choices of managers, pointing out further possibilities of research regarding the comparability of financial information. Along with the accounting practice, research contributes by indicating to users the comparability level of accounting practices between companies over time, as well as between countries. Concerning the organizations in charge of promoting the accounting convergence process, it is expected to provide evidence that there is a mean comparability degree between the accounting statements in relation to IPs, as well as warn them about the fact that there is a decrease in this comparability over the analyzed periods.

This research is limited as for the generalization of results, since the empirical research took place only in two countries and solely with IPs. For further research, it is suggested to increase the number of countries analyzed, in order to determine whether, in fact, the comparability observed herein applies to a larger number of countries. Increasing the number of accounting standards to be observed also becomes appropriate, in order to identify the comparability of financial statements through a larger number of valid accounting choices. 


\section{References}

Andrade, M. E. M. C., Silva, D. M., \& Malaquias, R. F. (2013): Escolhas contábeis em propriedades para investimento. Revista Universo Contábil, 9(3), 22-37.

Barth, M. E. (2008). Global financial reporting: implications for U.S. academics. American Accounting Association, 83(5), 1159-1179.

Bennett, B., Bradbury, M. E., \& Prangnell, H. (2006). Rules, principles and judgments in accounting standards. Abacus, 42(2), 189-204.

Bertoni, M., \& Derosa; B. (2005). Comprehensive income, fair value and conservatism: a conceptual framework for reporting financial performance. In $5^{\text {th }}$ International Conference on European Integrations, Competition and Cooperation, Lovran. Recuperado de http://ssrn.com/abstract $=2239303$

Cairns, D., Massoudi, D., Taplin, R., \& Tarca, A. (2011). IFRS fair value measurement and accounting policy choice in the United Kingdom and Australia. The British Accounting Review, 43, 1-21.

Carmo, C. H. S., Ribeiro, A. M., \& Carvalho, L. N. G. (2011). Convergência de fato ou de direito? A influência do sistema jurídico na aceitação das normas internacionais para pequenas e médias empresas. Revista Contabilidade \& Finanças, 22(57), 242-262.

Christensen,.H. B., \& Nikolaev, V. V. (2013). Does fair value accounting for non-financial assets pass the market test? Review of Accounting Studies, 18, 734-775.

Cole, V., Branson, J., \& Breesch, D. (2009). How to measure the comparability of financial statements? International Journal of Managerial and Financial Accounting, 1(4), 379-397.

Danbolt, J., \& Rees, W. (2008). An experiment in fair value accounting: UK investment vehicles. European Accounting Review, 17(2), 271-303.

Demaria, S., \& Dufour, D. (2007). First time adoption of IFRS, fair value option, conservatism: evidences from French listed companies. Recuperado de http://hal.archives-ouvertes.fr/docs/00/26/61/89/PDF/ First_adoption_and_fair_value_Demaria_Dufour.pdf

Dietrich, J. R., Harris, M. S., \& Muller, K. A. (2001). The reliability of investment property fair value estimates. Journal of Accounting and Economics, 30, 125-158

Fields, T. D., Lys, T. Z., \& Vincent, L. (2001). Empirical research on accounting choice. Journal of Accounting and Economics, 31, 255-307.

Freri, M. R., \& Salotti, B. M. (2013). Comparabilidade de empresas administradoras de shopping centers do mercado de capitais brasileiro. Revista de Contabilidade do Mestrado em Ciências Contábeis da UERJ, 18(1), 28-45.

Gabriel, F., \& Corrar, L. J. (2010). Gerenciamento de resultados e de capital no sistema bancário brasileiro: uma investigação empírica nas aplicações em títulos e valores mobiliários. Revista de Contabilidade do Mestrado em Ciências Contábeis da UERJ, 15(2), 49-62.

Haller, A., \& Wehrfritz, M. (2013). The impact of national GAAP and accounting traditions on IFRS policy selection: evidence from Germany and the UK. Journal of International Accounting, Auditing and Taxation, 22, 39-56.

Herrmann, D., Saudagaran, S. M., \& Thomas, W. B. (2006). The quality of fair value measures for property, plant, and equipment. Accounting Forum, 30, 43-59.

Hosmer, D. W., \& Lemeshow; S. (2000). Applied logistic regression (2a ed.) New York: John Wiley \& Sons.

International Accounting Standards Board. (2013). The Conceptual Framework for Financial Reporting. Recuperado de http://www. iasplus.com/en/projects/major/cf-iasb

Jaafar, A., \& Mcleay, S. (2007). Country effects and sector effects on the harmonization of accounting policy choice. Abacus, 43(2), 156-189.

Johnston, J., \& Dinardo, J. (2001). Métodos econométricos (4a ed.). Lisboa: McGraw-Hill.
Lemes, S., \& Carvalho, L. N. G. (2009). Comparabilidade entre o resultado em BR GAAP e U.S. GAAP: evidências das companhias brasileiras listadas nas bolsas norte-americanas. Revista Contabilidade \& Finanças, 20(50), 25-45.

Lorencini, F. D., \& Costa, F. M. (2012). Escolhas contábeis no Brasil: identificação das características das companhias que optaram pela manutenção versus baixa dos saldos do ativo diferido. Revista Contabilidade e Finanças, 23(58), 52-64.

Lourenço, I. (2009). IFRS accounting policy alternatives and the value relevance of accounting numbers: evidence from the EU Real Estate Industry. FSR Forum, 5(1), 1-11.

Macedo, M. A. S., Machado, M. A. V., \& Machado, M. R. (2013). Análise da relevância da informação contábil no Brasil num contexto de convergência às normas internacionais de contabilidade. Revista Universo Contábil, 9(1), 65-85.

Muller III, K. A, \& Riedl, E. J. (2002). External monitoring of property appraisal estimates and information asymmetry. Journal of Accounting Research, 40(3), 865-881.

Muller, K. A., Riedl, E. J., \& Sellhorn, T. (2008). Causes and consequences of choosing historical cost versus fair value. Recuperado de http:// nd.edu/ carecob/May2008Conference/Papers/RiedlMRS03062008. pdf

Nellessen, T., Zuelch, H. (2011). The reliability of investment property fair values under. Journal of Property Investment and Finance, 29(1), 59-73.

Nobes, C. (1998). Towards a general model of the reasons for international differences in financial reporting. Abacus, 34(2), 162-187.

Oliveira, V. A., \& Lemes, S. (2011). Nível de convergência dos princípios contábeis brasileiros e norte-americanos às normas do IASB: uma contribuição para a adoção das IFRS por empresas brasileiras. Revista Contabilidade \& Finanças, 22(56), 155-173.

Shaffer, S. (2010). Fair value accounting: villain or innocent victim. Exploring the links between fair value accounting, bank regulatory capital and the recent financial crisis. The quantitative analysis unit of the Federal Reserve Bank of Boston (Working paper QAU10-01). Recuperado de http://bostonfed.org/bankinfo/qau/wp/2010/qau1001.pdf

Souza, F. E. A., Silva, M. H., \& Costa, P. S. (2013). A comparabilidade das escolhas contábeis na avaliação de ativos intangíveis de companhias abertas brasileiras. In $16^{\circ}$ Seminários em Administração, São Paulo, SP. Recuperado de http://semead6.tempsite.ws/16semead/resultado/ trabalhosPDF/554.pdf

Taplin, R. H. (2004). A unified approach to the measurement of international accounting harmony. Accounting and Business Research $34(1), 57-73$

Taplin, R. H. (2010). Statistical inference using the T-index to quantify the level of comparability between accounts. Accounting and Business Research, 40(1), 75-103.

Van Der Tas, L. G. (1988). Measuring harmonization of financial reporting practice. Accounting and Business Research, 18, 157-169.

Watts, R. L. (1992). Accounting choice theory and market-based research in accounting. British Accounting Review, 24, 235-267.

Watts, R. L., \& Zimmerman, J. L. (1986). Positive accounting theory. Upper Saddle River, NJ: Prentice Hall.

Correspondence Address:

Flaida Êmine Alves de Souza

Faculdade de Ciências Contábeis, Universidade Federal de Uberlândia Avenida João Naves de Ávila, 2121 - CEP: 38400-902

Campus Santa Mônica - Uberlândia - MG

E-mail: flaidaemine@yahoo.com.br 